\title{
MERCANTILIZAÇÃO DA EDUCAÇÃO SUPERIOR E O FAZER DOCENTE
}

\author{
Gaudêncio Frigotto ${ }^{1}$
}

Como é representada a mercantilização da educação superior hoje e o que levou a isso?

A mercantilização na verdade é transformação de um direito social e individual subjetivo em um serviço, uma mercadoria. Então os direitos são universais, os direitos a saúde, educação, etc. A mercantilização é quando esses direitos se adquirem no mercado, isto é, viram negócios. Então nós sabemos que hoje tanto a educação quanto a saúde viraram negócio, tem quantos aqui na Universidade que não têm um plano de saúde, então o plano de saúde não é um direito é um negócio, na verdade a mercantilização é a passagem de um direito social e subjetivo para colocar esse direito no âmbito da mercadoria e do mercado. 


\section{Em outras palavras é a fuga do Estado de suas obrigações?}

É o Estado que renuncia o seu dever de garantir o direito á todos de saúde e de educação e transfere isso ao mercado.

\section{E que mecanismos a sociedade tem para ter de volta esses direitos?}

Bem, essa é uma luta quase que revolucionária porque o processo histórico que levou a mercantilização é um processo que primeiramente se ligou, especialmente o trabalho da universidade mas não só a educação básica, a idéia de Estados nacionais, a idéia de construir o desenvolvimento de uma nação com sua língua, sua cultura, etc. Com os processos de mundialização do mercado e do capital é que começa uma pressão para os Estados retirarem a sua função social e serem uma espécie de garantia ao capital. Então só para dar um exemplo hoje se alguém precisa dez mil reais para construir um quarto dentro da nossa casa nós pagamos juros de 8 a $12 \%$, agora se a gente quer poupar dez mil reais para depois construir algo nós ganhamos 0,5\% de juro com correção, então os Estados hoje na verdade viraram garantias do mercado e não dos direitos social e está exatamente foi a virada a partir dos anos 1980 mas que no Brasil se realizou nos anos 1990. Os processos de privatização, os processos de delegação do Estado àquilo que era sua atribuição, à instituições privadas e o Estado passou a ser apenas avaliador ou controlador, as agências de controle também com pouco controle, nós podemos observar nas várias áreas dentro da saúde e da educação, do transporte que essas agências controlam pouco.

\section{Qual é a culpa dos governos nessa situação?}

A gente discutiu muito o que é o Estado neoliberal, na verdade o Estado neoliberal não é um Estado pequeno, e sim, como eu dizia anteriormente, é um Estado que é preposto no mercado e a culpa está exatamente do Estado se desfazer daquilo que é sua obrigação até constitucional por exemplo, no Brasil nós temos uma constituição que 
garante a educação básica, ensino fundamental e médio a todo cidadão no entanto nós, se quer, garantimos o ensino fundamental a todos cidadãos, então é o Estado que não cumpre a sua função constitucional.

\section{Que riscos gera a subordinação da docência, seja no ensino, na pesquisa ou na extensão, aos critérios mercantis?}

Como diz o historiador Eric Hobsbawm o mercado não tem pátria. O mercado exclui como o gás carbônico polui, então o risco é exatamente de deixar de cumprir a sua função fundamental que é de desenvolver conhecimento, cultura, arte como valores pra toda sociedade e toda a humanidade. O mercado é extremamente objetivo, ele busca o que serve e portanto o mercado não garante direitos, o que pode garantir direitos é uma esfera pública, o mercado ele busca o seu negócio, então o risco é de mediocrizar o conhecimento, mediocrizar a educação e inclusive com riscos ao próprio mercado porque por ele ser focalizado ele não tem a visão de uma totalidade que pode atingilo mesmo no campo dos negócios se você não tem uma visão estratégica, uma visão mais ampla do que o imediato do curto prazo você corre o risco de lá a frente falir. O grande risco é de exatamente deixar de cumprir o que é função precípua da educação que é gerar conhecimento, que seja um conhecimento patrimônio não do mercado mas das pessoas e da humanidade como diz esse historiador Eric Hobsbawm nós temos que insistir que as pessoas vem em primeiro lugar e não o mercado e que as pessoas não podem ser sacrificadas nesse sentido a educação tem que cumprir este ideário mais universal.

\section{E para o aluno, quais são os aspectos negativos?}

Para o aluno primeiramente é que ele tem que pagar um direito, então nós temos uma sociedade desigual porque uns tem a educação fundamental, média e superior gratuita e outros tem que ir ao mercado de ensino e comprar este direito. O segundo é que as instituições que entram numa lógica mercantilista preparam muito limitadamente este jovem porque lhe dão uma visão muito unidimensional e não uma base mais ampla 
que permite a ele ter autonomia de poder até mudar de área, ou de empresa ou de trabalho. Na medida em que você tem um ensino muito restrito voltado para os critérios de mercado eu diria desprepara para a cidadania e desprepara para ele ter meios de barganhar os seus direitos.

\section{Diante da lógica de mercado que existe no ensino superior, que riscos de sustentabilidade têm as universidades comunitárias e qual deve ser o compromisso dessas instituições, não estatais e que também não são privadas?}

Hoje há uma crise muito grande daquelas instituições que não tem como fim o lucro empresarial, no Brasil temos hoje as universidades chamadas de públicas que tem muito de privatizado internamente, as comunitárias e as empresarias, as empresarias são aquelas que tem o ensino como um negócio e investem o retorno do ensino em vacas, em produtos, em fazendas e em bancos. Nós temos fazendeiros, deputados, donos de marmoraria que fazem do ensino um negócio. O risco das comunitárias é que por elas terem compromissos públicos com a coletividade elas começam a padecer sua sustentabilidade financeira e agora então com a mercantilização da educação a distância ou do ensino a distância isto fica ainda mais grave. Agora eu acho que a própria Unochapecó é um exemplo de como com criatividade, com compromisso, com diálogo, com pesquisa ela busca seu nicho. Então eu diria que a sustentabilidade e ao mesmo elas terem excelência acadêmica, não se dobrarem ao mercado, terem organização interna e capacidade de negociação política, eu acho que a viabilidade das comunitárias está em elas terem organização entre elas e pressionarem por seus direitos de existirem e o que vai lhes dar credibilidade é exatamente a qualidade do que oferecem em ternos de ensino, pesquisa e extensão.

\section{Nota}

\footnotetext{
${ }^{1}$ Doutor em Educação, Professor na Faculdade de Educação da Universidade do Estado do Rio de Janeiro atuando no Programa Interdisciplinar de Pós-graduação em Políticas Públicas e Formação Humana e Professor titular colaborador na Universidade Federal Fluminense.
} 